\title{
DEREGULASI DAN DEBIROKRATISASI PENYELENGGARAAN PELAYANAN PERIJINAN
}

\author{
Ari Purwadi \\ Fakultas Hukum Universitas Wijaya Kusuma Surabaya \\ e-mail: aripurwadi.fhuwks@yahoo.co.id
}

\begin{abstract}
ABSTRAK
Desentralisasi pelayanan publik untuk mewakili upaya pemerintah setempat untuk membuat debirokratisasi. Melalui konsep menemukan kembali pemerintah yang dapat digunakan untuk reformasi birokrasi dalam pengelolaan pelayanan publik. Debirokratisasi publik dan deregulasi bahwa spesifikasi manajemen orientasi umum pelayanan publik dan juga panduan untuk menilai kinerja pelayanan publik. Deregulasi pelayanan perizinan dengan mengorganisir layanan perijinan terpadu di pemerintah daerah.
\end{abstract}

Kata Kunci: Deregulasi, Debirokratisasi, Pelayanan Perizinan

\section{ABSTRACT}

Decentralize the public service to local government represent the effort to do the debureaucracyzation. Through concept of Reinventing Government can be used for the reform of bureaucracy in public service management. Debureaucracyzation and deregulation public service as specifying of common guidance of public service management and also guidance of public service performance assessment. Deregulation to management of licensing service as arranging of inwrought licensing service in local government.

Keywords: deregulation, debureaucracyzation, licensing service

\section{PENDAHULUAN}

Pelayanan publik adalah satu di antara banyak kewenangan pemerintah yang diserahkan kepada daerah. Pelayanan publik yang didesentralisasikan itu berwujud dua hal. Yaitu, pelayanan yang bersifat substantif dan administratif.

Pelayanan yang bersifat substantif adalah pelayanan dasar dan harus ada karena menjadi kebutuhan hidup warga negara. Misalnya, pelayanan pendidikan dan kesehatan. Karena pentingnya pelayanan pendidikan dan kesehatan itu, UUD 1945 juga turut mengaturnya. Khusus untuk pelayanan pendidikan, UUD 1945 mewajibkan pemerintah mengalokasikan 20 persen APBN untuk bidang pendidikan. Kewenangan pengadaan, penyelenggaraan, dan pengelolaannya pun tidak sepenuhnya diserahkan kepada pemerintah daerah. Pemerintah pusat masih memegang peran dominan, terutama dalam hal kebijakan dan pendanaan.

Pelayanan publik yang bersifat administrasi adalah semua jenis layanan kepada warga negara berupa surat-menyurat, perijinan, dan pencatatan kependudukan. Atau, biasanya dibedakan menjadi pelayanan perijinan dan non-perijinan. Seiring dengan era otonomi daerah, pelayanan jenis itu banyak diserahkan kepada daerah.

Alasan utama penyerahan urusan administrasi tersebut kepada daerah adalah karena pertimbangan besarnya jumlah penduduk dan luasnya wilayah Indonesia.

Untuk menilai kondisi layanan administrasi, JPIP (The Jawa Pos Institute of Pro Otonomi) Paparan Hasil Monitoring Otonomi Daerah di Jatim 2007 (4): Memutus Rantai Panjang Layanan Publik, 29 Nopember 2007 menggunakan 4 (empat) indikator. Yaitu, dari segi kualitas pelayanan, aksesi bilitas yang meliputi keterjangkauan jarak dan harga, equity (perlakuan yang adil bagi orang miskin), transparansi, dan akuntabilitas. Dari sisi kualitas, sebagian besar daerah berupaya meningkatkan mutu pelayanan. Caranya, memanfaatkan dan mengembangkan teknologi informasi (TI). Penerapan TI tersebut untuk pelayanan perijinan dan non-perijinan. Dari 38 kabupaten/kota di Jawa Timur, hanya tiga daerah yang mengaitkan (link) layanan perijinan dengan website yang mereka miliki. Namun, meski sudah terkoneksi dengan internet, pelayanannya belum bisa dilakukan secara online. Di website tersebut hanya berisi persyaratan-persyaratan administrasi untuk mengurus perijinan. Jadi, sifatnya baru sebatas informasi layanan. Misalnya, mengurus surat ijin usaha dan perdagangan (SIUP). Persyaratan yang harus dipenuhi adalah fotokopi KTP, NPWP, ijin HO, sertifikat kepemilikan tanah, dan bangunan. Namun, proses mengisi formulir dan transaksi 
pembayaran tidak bisa dilakukan secara online. Demikian juga, layanan administrasi nonperijinan sudah banyak daerah yang memanfaatkan TI. Misalnya, untuk layanan KTP, KK, dan sertifikatsertifikat. Untuk layanan KTP, sudah ada 15 daerah yang menerapkan sistem informasi administrasi kependudukan (SIAK).

Sistem itu sebenarnya bukan inisiatif daerah, tapi merupakan program pusat yang diperkenalkan pada 2004 melalui Keppres Nomor 8 Tahun 2004. SIAK bertujuan membangun sistem informasi kependudukan mulai tingkat kecamatan hingga pemerintah pusat di Jakarta. Dalam sistem itu, juga diperkenalkan nomor induk kependudukan (NIK) yang berlaku secara nasional. Dengan SIAK dan NIK, kasus double KTP tidak akan terjadi lagi. Pemerintah kabupaten kota menindak lanjuti sistem dengan membangun jaringan komputer yang online antara dinas yang mengurusi kependudukan catatan sipil dan kecamatan-kecamatan yang berada di kabupaten atau kota. Server atau database kependudukan berada di dinas. Dengan sistem itu, pembuatan KTP dan KK bisa dilakukan di kantor kecamatan. Meski sudah menggunakan TI, penyelesaian KTP dan KK masih bervariasi antar daerah. Ada daerah yang menjanjikan 1 jam selesai, 1 hari selesai, atau 3 hari baru selesai. Alasannya, data base yang dipunyai dinas belum sepenuhnya up to date. Dengan demikian, diperlukan verifikasi terlebih dahulu sebelum KTP dicetak.

Kendala utama penggunaan TI yang selama ini dihadapi daerah adalah masalah sumber daya manusia. Banyak daerah masih menggunakan tenaga dan konsultan TI dari pihak swasta. Akibatnya, biaya yang dikeluarkan per tahun sangat mahal dan menimbulkan ketergantungan kepada konsultan. Kondisi itu juga sangat riskan. Ada satu kabupaten di Jawa Timur yang tidak bisa lagi mengoperasikan jaringan SIAK karena password jaringan tidak diberikan konsultan. Lebih parah lagi, ada satu kabupaten yang database kependudukannya dibawa lari oleh konsultan karena putus kontrak. Meski demikian, secara umum, pada layanan ini relatif sudah ada kemajuan dalam hal kecepatan dan kemudahan.

Dari sisi aksesibilitas, tidak berbeda jauh dari temuan tahun lalu bahwa pelimpahan kewenangan kepada kecamatan menjadi trend selama 3 tahun terakhir. Kewenangan yang dilimpahkan itu, misalnya, pengurusan KTP, KK, dan sertifikat kelahiran sudah bisa diproses dan diselesaikan di kecamatan. Prosesnya, ada yang sudah menerapkan sistem online dan manual.

Untuk memudahkan akses warga memperoleh layanan administrasi, ada satu kota di Jawa Timur yang merintis desentralisasi kewenangan perijinan dan nonperijinan pada kecamatan. Kota tersebut justru tidak akan membentuk kantor pelayanan terpadu, terpusat, atau satu atap. Itu menarik karena bertolak belakang dengan kecenderungan umum bahwa daerah cenderung membuat palayanan satu atap atau terpusat. Apalagi, ada Permendagri Nomor 24 Tahun 2006 yang mengharuskan daerah membentuk lembaga pelayanan perijinan satu atap.

Ditemukan juga, ada satu kecamatan di salah satu kabupaten yang menerapkan pelayanan prima untuk layanan administrasi. Kecamatan itu sedang berupaya keras meraih ISO 9001-2000 untuk layanan administrasi. Begitu seriusnya menerapkan layanan prima, jika ada warga yang kurang puas atas pelayanan yang diberikan staf kecamatan, warga bisa langsung mengirim short message service (SMS) kepada camat dan sekretaris daerah. Nomor handphonenya tertera dengan jelas di depan kantor kecamatan.

Fungsi SMS itu ternyata tidak hanya complain. Bila ada warga yang membutuhkan tanda tangan camat, namun camat tidak berada di tempat, warga bisa langsung mengirimkan SMS kepada camat untuk segera kembali ke kantor kecamatan. Hanya satu kecamatan yang menerapkan cara pelayanan seperti itu.

Selain inovasi di tingkat kecamatan, ada dua kabupaten yang menerapkan sistem jemput bola untuk pelayanan administrasi kependudukan. Caranya, mengoperasikan mobil keliling ke desadesa. Satu kabupaten saat ini telah mengoperasikan dua unit mobil untuk pengurusan akta kelahiran di desa-desa. Satu kabupaten lain hanya mengoperasikan satu mobil yang mendatangi desadesa terpencil setiap dua minggu. Layanan yang diberikan meliputi pembuatan akta kelahiran, KK, KTP, bahkan legalisasi ijazah.

Dari sisi equity atau keberpihakan kepada warga miskin terlihat relatif ada kemajuan dalam layanan administrasi jika dibandingkan dengan temuan tahun lalu. Melonjaknya angka kemiskinan mendorong empati beberapa daerah untuk menggratiskan layanan administrasi kependudukan. Ide itu dilatarbelakangi banyaknya warga miskin yang tidak tercatat karena tidak mempunyai KTP dan tempat tinggal permanen. 
Ada empat kabupaten yang menggratiskan layanan KTP untuk keluarga miskin. Satu kabupaten lagi menerapkan sistem KTP bersubsidi untuk keluarga miskin. Bagi keluarga miskin penerima subsidi langsung tunai (SLT), pemkab memberikan bantuan subsidi Rp 3.000 per orang dengan syarat (1) membawa atau menunjukkan kartu kompensasi BBM (KKB); (2) membawa surat keterangan domisili yang dikeluarkan desa mengetahui camat. Pelaksanaan pelayanan KTP bersubsidi itu dilaksanakan Februari hingga Juni 2006 dan telah melayani $10.384 \mathrm{KTP}$, dengan jumlah total biaya subsidi Rp 31,2 juta.

Sama dengan temuan tahun lalu, ditemukan juga ada dua kota yang memberikan santunan kematian bagi warga yang ber-KTP dua kota tersebut. Jumlah santunannya masing-masing $\mathrm{Rp} 300$ ribu dan $\mathrm{Rp}$ 400 ribu. Dari indikator akuntabilitas dan partisipasi relatif ada kemajuan dibandingkan tahun lalu. Indikasinya, semakin banyak daerah yang memasang papan tarif di depan loket pelayanan administrasi. Selain di papan-papan pengumuman, tarif dipasang di website dan formulir isian. Bahkan, ada satu kabupaten yang memberikan stempel besarnya tarif pada setiap surat ijin yang dikeluarkan. Cara tersebut diterapkan untuk mencegah biaya siluman yang ditarik staf maupun para calo. Setidaknya, jika seorang pemohon ijin menitipkan pengurusan ijin kepada orang lain, biaya riil ijin tersebut tetap bisa diketahui secara jelas oleh pemohon ijin.

Dari sisi partisipasi, ada satu kota yang sudah menerapkan model kontrak layanan atau citizen's charter (CC) dalam layanan adminsitrasi kependudukan berupa KTP dan KK. Pemkot berupaya semakin mengakomodasi suara masyarakat. Dengan CC, kebutuhan dan kepentingan pengguna layanan merupakan pertimbangan utama dalam keseluruhan proses pelayanan publik. Wujud konkret $\mathrm{CC}$ adalah lahirnya kontrak pelayanan yang merupakan hasil persetujuan antara kecamatan sebagai penyedia layanan dan masyarakat pengguna layanan.

Isi CC mengatur tentang hak dan kewajiban masyarakat pengguna layanan dan kecamatan sebagai penyedia layanan. Misalnya, masyarakat berhak memperoleh pelayanan yang adil, memperoleh informasi prosedur, dan syaratsyarat pelayanan sesuai aturan secara jelas dan benar. Kecamatan berkewajiban memberikan informasi pelayanan kepada pengguna layanan. Selain mengatur hak dan kewajiban, hal itu juga mengatur standar pelayanan yang bersisi standar waktu pelayanan (10 menit untuk KTP), standar ruang pelayanan, alur pelayanan, sikap pelayanan, komplain, dan sanksi bagi kedua pihak. Temuan JETRO (2005) juga menunjukkan bahwa salah satu permasalahan utama investasi di Indonesia adalah ketidakpastian dan ketidakjelasan kebijakan pemerintah sebasar $67,7 \%$, sulit dan rumitnya perpajakan dan prosedur perdagangan sebesar $67,6 \%$. Angka-angka tersebut jelas menggambarkan bahwa iklim inverstasi di Indonesia amat buruk, sehingga menjadi wajar jika para investor enggan untuk menanamkan investasi di Indonesia.

Dampak dari sistem birokrasi yang berbelitbelit itu yang paling dirasakan warga adalah menimbulkan biaya yang sangat tinggi, karena banyak terjadi pungli dalam proses tersebut. Maka biaya untuk mengurus perijinan bisa mencapai $0,25 \%$ dari biaya produksi atau setara dengan $100 \%$ dari biaya perijinan resmi. Tentu saja hal tersebut sangat memberatkan terutama untuk kalangan pengusaha. Hal ini sangat berpengaruh terhadap iklim investasi.

Hasil penelitian Global Competi iveness Report tahun 2005-2006, ada beberapa faktor yang menghambat peluang bisnis suatu negara. Tetapi 4 faktor utamanya adalah birokrasi yang tidak efisien, infrasturktur buruk, regulasi perpajakan, dan korupsi. Indonesia berada di urutan 74 pada 2005 dari 100 negara yang disurvei. Semakin buruk kondisi tersebut, semakin investor menjauh dari Indonesia.

Faktor prosedur perijinan usaha yang panjang dan mahal merupakan salah satu penyebab memburuknya iklim usaha. Berdasarkan hasil studi International Finance Corporation (IFC) Bank Dunia pada tahun 2006, peringkat Indonesia menurun dari ke 131 pada tahun 2005, menjadi ke 135 pada tahun 2006, jika dibandingkan dengan negara lain di Asia, perijinan untuk memulai suatu usaha dari berbagai instansi pusat dan daerah membutuhkan 12 (dua belas) prosedur yang harus dilalui, dengan waktu yang dibutuhkan selama 97 hari. Biaya yang diperlukan sebesar US\$.1.110,- atau $86,7 \%$ dari income per capita income. Perbandingan di negara lain seperti, Malaysia dengan 9 prosedur, dan waktu yang dibutuhkan 30 hari, dan biaya yang diperlukan sebesar US\$.977 atau 19,7\% dari income per capita. Vietnam, dengan 11 prosedur, waktu yang dibutuhkan 50 hari, dan biaya yang diperlukan sebesar U\$276, atau 44,5\% dari income per capita. 
Hasil penelitian ini menekankan pada kemudahan berusaha. Disadari bahwa dampaknya dirasakan pada ekonomi biaya tinggi, peluang usaha, dan kepastian berusaha menjadi rendah.

\section{PARADIGMA BIROKRASI SEBAGAI PELAYAN MASYARAKAT}

Peningkatan pelayanan kepada masyarakat seperti yang terdapat dalam agenda Reinventing Government adalah pengembangan organisasi yang bermuara terwujudnya a smaller, better, faster and cheaper government. Reinventing Government yang digagas oleh David Osborne dan Ted Gaebler menemukan titik relevansinya dalam konteks optimalisasi pelayanan publik. 10 prinsip yang terkandung di dalamnya, yakni pemerintah seharusnya lebih berfungsi mengarahkan ketimbang mengayuh, memberi wewenang ketimbang melayani, menyuntikkan persaingan (kompetisi) dalam pemberian pelayanan, digerakkan oleh misi bukan peraturan, berorientasi pada hasil (outcome) bukan masukan (income), berorientasi pada pelanggan bukan pada birokrasi, menghasilkan ketimbang membelanjakan, mencegah ketimbang mengobati, desentralisasi dan pemerintah berorientasi pasar, seharusnya diterapkan oleh pemerintah untuk meningkatkan pelayanan publik kepada masyarakat.

Gagasan-gagasan Osborne dan Gaebler tentang Reinventing Government mencakup 10 prinsip untuk mewirausahakan birokrasi. Adapun 10 prinsip tersebut (dikutip dari tulisan Ahmad Zaenal Fanani, Optimalisasi Pelayanan Publik: Perspektif David Osborne dan Ted Gaebler, h; 4-8, didownload dari http://www.badilag. net/data/ARTIKEL tanggal 31 Maret 2010) adalah Pertama, pemerintahan katalis: mengarahkan ketimbang mengayuh. Artinya, jika pemerintahan diibaratkan sebagai perahu, maka peran pemerintah seharusnya sebagai pengemudi yang mengarahkan jalannya perahu, bukannya sebagai pendayung yang mengayuh untuk membuat perahu bergerak. Pemerintah entrepreneurial seharusnya lebih berkonsentrasi pada pembuatan kebijakan-kebijakan strategis (mengarahkan) daripada disibukkan oleh hal-hal yang bersifat teknis pelayanan (mengayuh).

Cara ini membiarkan pemerintah beroperasi sebagai seorang pembeli yang terampil, mendongkrak berbagai produsen dengan cara yang dapat mencapai sasaran kebijakannya. Wakil-wakil pemerintah tetap sebagai produsen jasa dalam banyak hal, meskipun mereka sering harus bersaing dengan produsen swasta untuk memperoleh hak istimewa. Tetapi para produsen jasa publik ini terpisah dari organisasi manajemen yang menentukan kebijakan. Upaya mengarahkan membutuhkan orang yang mampu melihat seluruh visi dan mampu menyeimbangkan berbagai tuntutan yang saling bersaing untuk mendapatkan sumber daya. Upaya mengayuh membutuhkan orang yang secara sungguh-sungguh memfokuskan pada satu misi dan melakukannya dengan baik. Kedua, pemerintahan milik rakyat: memberi wewenang ketimbang melayani. Artinya, birokrasi pemerintahan yang berkonsentrasi pada pelayanan menghasilkan ketergantungan dari rakyat. Hal ini bertentangan dengan kemerdekaan sosial ekonomi mereka. Oleh karena itu, pendekatan pelayanan harus diganti dengan menumbuhkan inisiatif dari mereka sendiri. Pemberdayaan masyarakat, kelompok-kelompok persaudaraan, organisasi sosial, untuk menjadi sumber dari penyelesaian masalah mereka sendiri. Pemberdayaan semacam ini nantinya akan menciptakan iklim partisipasi aktif rakyat untuk mengontrol pemerintah dan menumbuhkan kesadaran bahwa pemerintah sebenarnya adalah milik rakyat. Ketika pemerintah mendorong kepemilikan dan kontrol ke dalam masyarakat, tanggung jawabnya belum berakhir. Pemerintah mungkin tidak lagi memproduksi jasa, tetapi masih bertanggung jawab untuk memastikan bahwa kebutuhan-kebutuhan telah terpenuhi. Ketiga, pemerintahan yang kompetitif: menyuntikkan persaingan ke dalam pemberian pelayanan. Artinya, berusaha memberikan seluruh pelayanan tidak hanya menyebabkan resources pemerintah menjadi habis terkuras, tetapi juga menyebabkan pelayanan yang harus disediakan semakin berkembang melebihi kemampuan pemerintah (organisasi publik), hal ini tentunya mengakibatkan buruknya kualitas dan efektifitas pelayanan publik yang dilakukan mereka. Oleh karena itu, pemerintah harus mengembangkan kompetisi (persaingan) di antara masyarakat, swasta dan organisasi non pemerintah yang lain dalam pelayanan publik. Hasilnya diharapkan efisiensi yang lebih besar, tanggung jawab yang lebih besar dan terbentuknya lingkungan yang lebih inovatif.

Di antara keuntungan paling nyata dari kompetisi adalah efisiensi yang lebih besar sehingga mendatangkan lebih banyak uang, kompetisi memaksa monopoli pemerintah (atau swasta) 
untuk merespon segala kebutuhan pelanggannya, kompetisi menghargai inovasi, dan kompetisi membangkitkan rasa harga diri dan semangat juang pegawai negeri. Keempat, pemerintahan yang digerakkan oleh misi: mengubah organisasi yang digerakkan oleh peraturan. Artinya, pemerintahan yang dijalankan berdasarkan peraturan akan tidak efektif dan kurang efisien, karena bekerjanya lamban dan bertele-tele. Oleh karena itu, pemerintahan harus digerakkan oleh misi sebagai tujuan dasarnya sehingga akan berjalan lebih efektif dan efisien. Karena dengan mendudukkan misi organisasi sebagai tujuan, birokrat pemerintahan dapat mengembangkan sistem anggaran dan peraturan sendiri yang memberi keleluasaan kepada karyawannya untuk mencapai misi organisasi tersebut. Di antara keunggulan pemerintah yang digerakkan oleh misi adalah lebih efisien, lebih efektif, lebih inovatif, lebih fleksibel, dan lebih mempuyai semangat yang tinggi ketimbang pemerintahan yang digerakkan oleh aturan. Kelima, pemerintahan yang berorientasi hasil: membiayai hasil, bukan masukan. Artinya, bila lembagalembaga pemerintah dibiayai berdasarkan masukan (income), maka sedikit sekali alasan mereka untuk berusaha keras mendapatkan kinerja yang lebih baik. Tetapi jika mereka dibiayai berdasarkan hasil (outcome), mereka menjadi obsesif pada prestasi. Sistem penggajian dan penghargaan, misalnya, seharusnya didasarkan atas kualitas hasil kerja bukan pada masa kerja, besar anggaran dan tingkat otoritas. Karena tidak mengukur hasil, pemerintahan-pemerintahan yang birokratis jarang sekali mencapai keberhasilan. Mereka lebih banyak mengeluarkan untuk pendidikan negeri, namun nilai tes dan angka putus sekolah nyaris tidak berubah. Mereka mengeluarkan lebih banyak untuk polisi dan penjara, namun angka kejahatan terus meningkat. Keenam, pemerintahan berorientasi pelanggan: memenuhi kebutuhan pelanggan, bukan birokrasi. Artinya, pemerintah harus belajar dari sektor bisnis di mana jika tidak fokus dan perhatian pada pelanggan (customer), maka warga negara tidak akan puas dengan pelayanan yang ada atau tidak bahagia. Oleh karena itu, pemerintah harus menempatkan rakyat sebagai pelanggan yang harus diperhatikan kebutuhannya. Pemerintah harus mulai mendengarkan secara cermat para pelanggannya, melaui survei pelanggan, kelompok fokus dan berbagai metode yang lain. Tradisi pejabat birokrasi selama ini seringkali berlaku kasar dan angkuh ketika melayani warga masyarakat yang datang keistansinya. Tradisi ini harus diubah dengan menghargai mereka sebagai warga negara yang berdaulat dan harus diperlakukan dengan baik dan wajar. Di antara keunggulan sistem berorientasi pada pelanggan adalah memaksa pemberi jasa untuk bertanggung jawab kepada pelanggannya, mendepolitisasi keputusan terhadap pilihan pemberi jasa, merangsang lebih banyak inovasi, memberi kesempatan kepada warga untuk memilih di antara berbagai macam pelayanan, tidak boros karena pasokan disesuaikan dengan permintaan, mendorong untuk menjadi pelanggan yang berkomitmen, dan menciptakan peluang lebih besar bagi keadilan. Ketujuh, pemerintahan wirausaha: menghasilkan ketimbang membelanjakan. Artinya, sebenarnya pemerintah mengalami masalah yang sama dengan sektor bisnis, yaitu keterbatasan akan keuangan, tetapi mereka berbeda dalam respon yang diberikan. Daripada menaikkan pajak atau memotong program publik, pemerintah wirausaha harus berinovasi bagaimana menjalankan program publik dengan dengan sumber daya keuangan yang sedikit tersebut. Dengan melembagakan konsep profit motif dalam dunia publik, sebagai contoh menetapkan biaya untuk public service dan dana yang terkumpul digunakan untuk investasi membiayai inovasi-inovasi di bidang pelayanan publik yang lain. Dengan cara ini, pemerintah mampu menciptakan nilai tambah dan menjamin hasil, meski dalam situasi keuangan yang sulit. Kedelapan, pemerintahan antisipatif: mencegah daripada mengobati. Artinya, pemerintahan tradisional yang birokratis memusatkan pada penyediaan jasa untuk memerangi masalah. Misalnya, untuk menghadapi sakit, mereka mendanai perawatan kesehatan. Untuk meng-hadapi kejahatan, mereka mendanai lebih banyak polisi. Untuk memerangi kebakaran, mereka membeli lebih banyak truk pemadam kebakaran. Pola pemerintahan semacam ini harus diubah dengan lebih memusatkan atau berkonsentrasi pada pencegahan. Misalnya, membangun sistem air dan pembuangan air kotor, untuk mencegah penyakit; dan membuat peraturan bangunan, untuk mencegah kebakaran. Pola pencegahan (preventif) harus dikedepankan daripada pengobatan mengingat persoalanpersoalan publik saat ini semakin kompleks, jika tidak diubah (masih berorientasi pada pengobatan) maka pemerintah akan kehilangan kapasitasnya untuk memberikan respon atas masalah-masalah 
publik yang muncul. Kesembilan, pemerintahan desentralisasi: dari hierarki menuju partisipasi dan tim kerja. Artinya, pada saat teknologi masih primitif, komunikasi antar berbagai lokasi masih lamban, dan pekerja publik relatif belum terdidik, maka sistem sentralisasi sangat diperlukan. Akan tetapi, sekarang abad informasi dan teknologi sudah mengalami perkembangan pesat, komunikasi antardaerah yang terpencil bisa mengalir seketika, banyak pegawai negeri yang terdidik dan kondisi berubah dengan kecepatan yang luar biasa, maka pemerintahan desentralisasilah yang paling diperlukan. Tak ada waktu lagi untuk menunggu informasi naik ke rantai komando dan keputusan untuk turun. Beban keputusan harus dibagi kepada lebih banyak orang, yang memungkinkan keputusan dibuat "ke bawah" atau pada "pinggiran" ketimbang mengonsentrasikannya pada pusat atau level atas. Kerjasama antara sektor pemerintah, sektor bisnis dan sektor civil socity perlu digalakkan untuk membentuk tim kerja dalam pelayanan publik. Dan prinsip yang kesepuluh adalah pemerintahan berorientasi pasar: mendongkrak perubahan melalui pasar. Artinya, daripada beroperasi sebagai pemasok masal barang atau jasa tertentu, pemerintahan atau organisasi publik lebih baik berfungsi sebagai fasilitator dan pialang dan menyemai pemodal

PARADIGMA LAMA

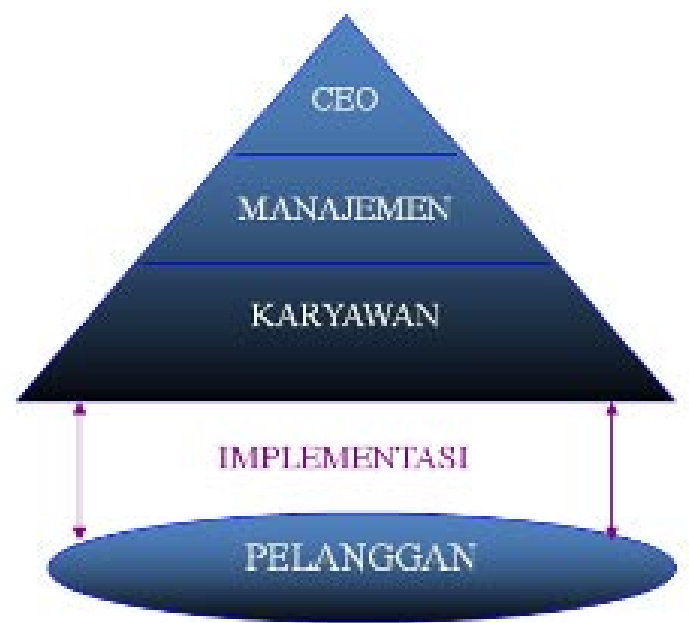

pada pasar yang telah ada atau yang baru tumbuh. Pemerintahan entrepreneur merespon perubahan lingkungan bukan dengan pendekatan tradisional lagi, seperti berusaha mengontrol lingkungan, tetapi lebih kepada strategi yang inovatif untuk membentuk lingkungan yang memungkinkan kekuatan pasar berlaku. Pasar di luar kontrol dari hanya institusi politik, sehingga strategi yang digunakan adalah membentuk lingkungan sehingga pasar dapat beroperasi dengan efisien dan menjamin kualitas hidup dan kesempatan ekonomi yang sama.

Dalam rangka melakukan optimalisasi pelayanan publik, 10 prinsip di atas seharusnya dijalankan oleh pemerintah sekaligus, dikumpulkan semua menjadi satu dalam sistem pemerintahan, sehingga pelayanan publik yang dilakukan bisa berjalan lebih optimal dan maksimal. 10 prinsip tersebut bertujuan untuk menciptakan organisasi pelayanan publik yang smaller (kecil, efisien), faster (kinerjanya cepat, efektif) cheaper (operasionalnya murah) dan kompetitif. Dengan demikian, pelayanan publik oleh birokrasi kita bisa menjadi lebih optimal dan akuntabel.

Paradigma pelayanan telah terjadi pembalikan metal model pada birokrat dari keadaan yang lebih suka dilayani menuju pada lebih suka melayani. Yang pertama menempatkan pemimpin puncak birokrasi pada piramida tertinggi dengan warga negara (customer) berada pada posisi terbawah. Sebaliknya yang kedua menempatkan warga negara (customer) berada pada puncak primida dengan pemimpin birokrasi berada pada posisi paling bawah. Hal ini digambarkan sebagai berikut:

\section{PARADIGMA BARU}

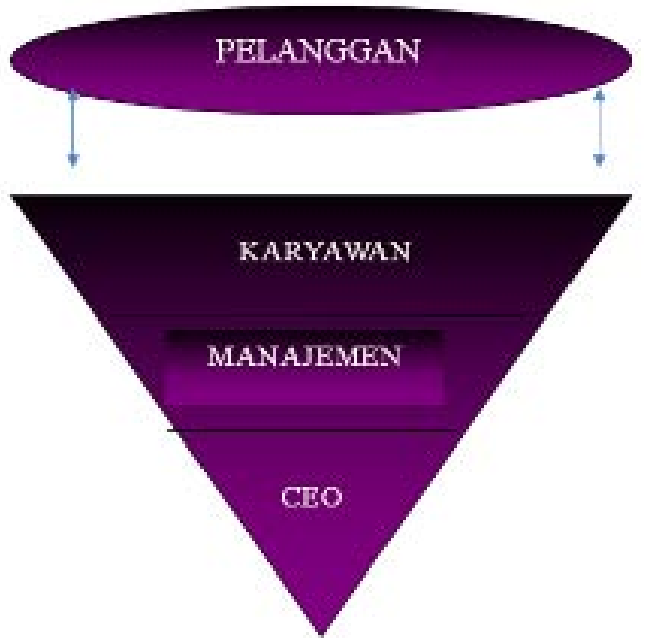

\section{REFORMASI BIROKRASI DALAM PELAYANAN PERIJINAN}

Perubahan paradigma pemerintahan dari sentralitis menuju desentralistis yang ditandai dengan kebijakan otonomi daerah membawa nuasa baru dalam penyelenggaraan pemerintah daerah sebagai upaya untuk lebih memandirikan daerah 
dan memberdayakan masyarakat. Perubahan paradigma tersebut sekaligus mencirikan perubahan volume atau beban tugas pemerintah daerah dalam menampung seluruh urusan yang diserahkan yang nantinya akan diwadahi dalam struktur organisasi perangkat daerah.

Reformasi birokrasi baik pada tingkat pemerintah pusat maupun pemerintah daerah merupakan kebutuhan dalam upaya untuk mewujudkan "good public governance".Tata kepemerintah an yang baik merupakan suatu konsepsi tentang penyelenggaraan pemerintahan yang bersih, demokratis, dan efektif sesuai dengan cita-cita terbentuknya suatu masyarakat madani. Tata kepemerintahan yang baik merupakan suatu bentuk pemerintahan dan administrasi publik yang mampu bekerja secara efisien, yakni mampu memenuhi kebutuhan rakyat. Reformasi birokrasi di tingkat pemerintah daerah diarahkan untuk melakukan penyempurnaan terhadap semua kelemahan atau kekurangan yang terjadi pada pelaksanaan kebijakan desentrali sasi sebagai ujung tombak dalam mengem-bang fungsi utama birokrasi yaitu pelayanan publik yang secara langsung menyentuh upaya pemenuhan kepentingan atau kebutuhan masyarakat.

Kepercayaan masyarakat terhadap pemerintah menjadi menurun ketika berurusan dengan dokumen perijinan yang terkesan berbelit-belit. Padahal dokumen perijinan yang seharusnya bisa diproses dengan cepat menjadi lambat. Perijinan yang berbelit adalah penyakit lama birokrasi. Reformasi sektor pelayanan perijinan dimulai dengan dikeluarkannya Peraturan Menteri Dalam Negeri (Permendagri) Nomor 24 Tahun 2006 tentang Pedoman Penyelenggaraan Pelayanan Terpadu Satu Pintu (PPTSP). Pelayanan publik yang bersifat adminitratif, yang meliputi pelayanan perijinan dan pelayanan non-perijinan. Khusus untuk reformasi birokrasi untuk pelayanan perijinan juga telah dikeluarkan Permendagri Nomor 20 Tahun 2008 tentang Pedoman Organisasi Dan Tatakerja Unit Pelayanan Perijinan Terpadu Di Daerah. Permendagri Nomor 20 Tahun 2008 ini merupakan pelaksanaan dari Pasal 47 Peraturan Pemerintah Nomor 41 Tahun 2007 tentang Organisasi Perangkat Daerah.

Semua produk hukum tersebut merupakan upaya untuk deregulasi dan debirokratisasi perijinan. Deregulasi dan debirokratisasi perijinan usaha merupakan kebijakan yang diambil untuk memperbaharui proses penyelenggaraan pelayanan perijinan kepada masyarakat oleh pemerintah, selama ini dirasakan menghambat atau tersendat, untuk disempurnakan melalui proses percepatan pelayanan dengan memotong mata rantai pengaturan pelayanan dan unit organisasi yang terlibat. Proses penyempurnaannya harus terpadu, lintas instansi, lintas sektor, dan dikoordinasikan oleh satu instansi pemerintah yang memiliki kompetensi dan kewenangan untuk mengambil kebijakan, mengurangi aturan prosedur, dan rasionalisasi kelembagaan pemerintah.

Pelayanan perijinan terpadu adalah bentuk implementasi reformasi birokrasi yang sedang dilaksanakan, karena birokrasi telah menjadi lembaga yang boros, inefisien, dan lamban. Hal ini kemudian memunculkan praktik pungli dan calo. Bahkan, dulu sering ada sindiran "Kalau bisa lama kenapa mesti dipercepat?" maka perlu dibuat pemangkasan birokrasi untuk memberi kemudahan pelayanan bagi masyarakat agar lebih cepat, mudah, sederhana, dan transparan dalam mengurus perizinan. Ini adalah upaya untuk mengintegrasikan sistem pelayanan yang dulu tersebar di unit-unit, kini menjadi terpadu. Problem pelayanan yang tidak transparan, sistem yang tertutup, tidak ada standar pelayanan, membuat pelayanan sangat lamban.

Sebenarnya, trend pembentukan pelayanan terpadu sudah banyak dijumpai di daerah sejak otonomi daerah digulirkan pada tahun 2001. Modelnya biasanya berbentuk pelayanan satu atap. Bentuk lembaganya bervariasi. Ada yang berbentuk Unit, Kantor, Badan, maupun Dinas. Namanya pun bermacam-macam mulai Unit Pelayanan Terpadu (UPT), Kantor Pelayanan Terpadu (BPT). Ada juga yang menamakan Dinas Perijinan dan Penanaman Modal.

Terhadap keberadaan Penyelenggaraan Pelayanan Terpadu Satu Pintu (PTSP) terdapat dua kelompok tanggapan. Kelompok pertama adalah yang mendukung keberadaan pelayanan ini. Kelompok ini melihat pada respon yang baik dari masyarakat maupun aparat pemerintah di beberapa kabupaten atau kota terhadap keberadaan pelayanan terpadu. Contoh keberhasilan itu adalah Kabupaten Sragen yang mendapatkan penghargaan untuk mutu pelayanan terpadunya dan menjadi contoh bagi kabupaten atau kota lain. Kebijakan pelayanan terpadu dapat mendukung terciptanya aspekaspek dalam good governance dan memperkecil kemungkinan terjadinya kolusi dan korupsi.

Kelompok kedua adalah kelompok yang 
menentang keberadaan PTSP ini. Keberadaan pelayanan terpadu tidak akan berjalan efektif karena instansi hanya memindahkan orang dan tempat. Bahkan di beberapa aspek menimbulkan kerugian bagi masyarakat, misalnya yang semula letak pengurusan dekat, dengan adanya kebijakan pelayanan terpadu satu pintu pengurusannya menjadi lebih jauh. Karena tidak ada altenatif pengurusan, maka iklim kompetisi dalam memberikan pelayanan menjadi tidak ada.

\section{KEBIJAKAN PEMERINTAH DALAM MEMPERLUAS KOMPETENSI PELAYANAN PERIJINAN}

Berkembangnya ragam pelayanan publik dan kian tingginya tuntutan pelayanan publik yang lebih efisien, cepat, fleksibel, berbiaya rendah serta memuaskan, akan menjadikan negara pada posisi "kewalahan" manakala masih tetap memaksakan dirinya sebagai satu-satunya institusi yang "paling sah" dalam memberikan pelayanan. Bahkan jika ia tetap menempatkan diri sebagai agen tunggal dalam memberikan pelayanan, pastilah akan berada pada posisi "payah". Karena itu, mengurus sesuatu yang semestinya tidak perlu diurus, haruslah ditinggalkan oleh negara; agar lebih berkonsentrasi pada urusanurusan yang lebih strategis dan krusial.

Karena itu, konsep desentralisasi sebenarnya bermaksud untuk mengurangi beban negara yang berlebihan dan tidak semestinya. Ia merekomendasikan berbagai hak, wewenang, tugas dan tanggungjawab dengan masyarakat (baik terorganisir maupun tidak) dalam mengurusi dan memberikan pelayanan publik agar tidak semakin "kepayahan". Bahkan ia memberikan rekomendasi agar rakyat diperbolehkan mengurusi dirinya sendiri; dan tidak serba menyerahkan segala urusannya kepada negara.

Kebijakan pemerintah dalam memperluas kompetensi pelayanan sudah sejak diterbitkan Keputusan Menteri Pendayagunaan Aparatur Negara Nomor 63/KEP/M.PAN/7/2003 tentang Pedoman Umum Penyelenggaraan Pelayanan Publik.

Kemudian kebijakan pelayanan publik dituangkan dan Peraturan Menteri Pendayagunaan No. PER/26/M.PAN/05/2006 tentang Pedoman Penilaian Kinerja Pelayanan Publik, yang kemudian diubah dengan Peraturan Menteri Negara Pendayagunaan Aparatur Negara Dan Reformasi Birokrasi Nomor 7 Tahun 2010 tentang Pedoman
Penilaian Kinerja Unit Pelayanan Publik. Dalam Rangka Pelaksanaan Kompetisi antar Kabupaten atau Kota, yang mengatur antara lain: komponen dan indikator penilaian sebagai berikut: Pertama, Kebijakan deregulasi dan debirokratisasi pelayanan publik; Kedua, Kebijakan peningkatan partisipasi masyarakat; Ketiga, Kebijakan pemberian penghargaan dan penerapan sanksi; Keempat, Pembinaan teknis terhadap unit pelayanan publik; Kelima, Kebijakan korportisasi unit pelayanan publik; Keenam, Pengembangan manajemen pelayanan; Ketujuh, Kebijakan peningkatan profesionalisme pejabat atau pegawai di bidang pelayanan publik; Kedelapan, Penghargaan di bidang peningkatan kualitas pelayanan publik; Kesembilan, Kebijakan pembangunan kemasyarakatan dan kesejahteraan; Kesepuluh, Kebijakan dalam mendorong pembangunan ekonomi daerah; Kesebelas, Kebijakan pengembangan dan pemanfaatan $e$ government; Keduabelas, Penerapan standar ISO 9001-2000.

Pendayagunaan aparatur negara pada dasarnya adalah pembinaan, penertiban dan penyempurnaan aparatur negara baik dari aspek kelembagaan, sumberdaya manusia aparatur, tata laksana, dan pengawasan. Percepatan pendayagunaan aparatur negara dilakukan melalui reformasi birokrasi dengan sasaran mengubah pola pikir (mindset), budaya kerja (culture-set), dan sistem manajemen pemerintahan, sehingga peningkatan kualitas pelayanan publik lebih cepat tercapai. Upaya tersebut dilaksanakan secara berkelanjutan dan berkesinambungan yang berujung pada pelayanan publik yang prima.

Dalam rangka melaksanakan Undang-Undang Nomor 25 tahun 2009 tentang Pelayanan Publik terutama dalam melaksanakan evaluasi kinerja pelayanan publik serta dalam upaya mempercepat peningkatan kualitas pelayanan publik, maka diperlukan pemberian apresiasi terhadap unit pelayanan publik yang telah melaksanakan pelayanan prima yaitu pelayanan yang cepat, tepat, murah, aman, berkeadilan dan akuntabel, berupa pemberian penghargaan sebagai bagian dari pembinaan aparatur negara. Pemberi-an penghargaan tersebut merupakan langkah strategis dalam rangka mendorong upaya perbaikan dalam peningkatan kualitas pelayanan publik ialah dengan memberikan stimulus atau motivasi, semangat perbaikan dan inovasi pelayanan serta melakukan penilaian untuk mengetahui gambaran kinerja yang 
obyektif dari unit pelayanan.

Kebijakan reformasi birokrasi bagi penyelenggaraan pelayanan perijinan dituangkan dalam Permendagri Nomor 20 Tahun 2008 tentang Pedoman Organisasi dan Tatakerja Unit Pelayanan Perijinan Terpadu Di Daerah. Dalam rangka meningkatkan pelayanan masyarakat di bidang perijinan dibentuk unit pelayanan perijinan terpadu dengan sebutan Badan atau Kantor.

Sedangkan besaran organisasi Badan dan/atau Kantor ditetapkan berdasarkan klasifikasi besaran organisasi perangkat daerah. Kalau unit pelayanan perijinan terpadu menggunakan bentuk Badan apabila variabel besaran organisasi perangkat daerah mencapai nilai lebih dari 70 (tujuh puluh). Sedangkan kalau unit pelayanan terpadu menggunakan bentuk Kantor apabila variabel besaran organisasi perangkat daerah mencapai nilai kurang atau sama dengan 70 (tujuh puluh).

Untuk menghitung variabel besaran organisasi menggunakan pedoman pada Peraturan Pemerintah Nomor 41 Tahun 2007 tentang Organisasi Perangkat Daerah.

Pada lampiran Peraturan Pemerintah Nomor 41 Tahun 2007 ditetapkan Penetapan Variabel Besaran Organisasi Perangkat Daerah sebagai berikut: simplifikasi, keamanan dan kepastian. Dalam menyelenggarakan tugas tersebut Badan Perijinan Terpadu dan/atau Kantor Perijinan Terpadu menyelenggarakan fungsi: Pertama, pelaksanaan penyusunan program Badan dan/atau Kantor; Kedua, penyelenggaraan pelayanan administrasi perijinan; Ketiga, pelaksanaan koordinasi proses pelayanan perijinan; Keempat, pelaksanaan administrasi pelayanan perijinan; Kelima, pemantauan dan evaluasi proses pemberian pelayanan perijinan.

Evaluasi Kinerja Penyelenggara Pelayanan Publik dilakukan oleh pimpinan unit pelayanan perijinan. Pimpinan penyelenggara pelayanan perijinan wajib secara berkala mengadakan evaluasi terhadap kinerja penyelenggaraan pelayanan perijinan. Kegiatan evaluasi ini dilakukan secara berkelanjutan dan hasilnya secara berkala dilaporkan kepada Bupati atau Walikota. Dalam melakukan evaluasi kinerja pelayanan publik harus menggunakan indikator yang jelas dan terukur sesuai ketentuan yang berlaku. Ketentuan dimaksud dapat mengacu pada Peraturan Menteri Negara Pendayagunaan Aparatur Negara Dan Reformasi Birokrasi Nomor 7 Tahun 2010 tentang Pedoman Penilaian Kinerja Unit Pelayanan Publik.

Untuk Kabupaten:

\begin{tabular}{clcc}
\hline No. & \multicolumn{1}{c}{ Variabel } & Kelas Interval & Nilai \\
\hline 1 & \multicolumn{1}{c}{2} & 3 & 4 \\
\hline 1. & JUMLAH PENDUDUK & 250.000 & 8 \\
& (jiwa) & $250.001-500.000$ & 16 \\
& Untuk Kabupaten di & $500.001-750.000$ & 24 \\
& Pulau Jawa dan Madura & $750.001-1.000 .000$ & 32 \\
& & $>1.000 .000$ & 40 \\
2. & LUAS WILAYAH (km2) & 500 & 7 \\
& Untuk Kabupaten di & $501-1.000$ & 14 \\
& Pulau Jawa dan Madura & $1.001-1.500$ & 21 \\
& & $1.501-2.000$ & 28 \\
& & $>2.000$ & 35 \\
3. JUMLAH APBD & Rp. 200.000 .000 .000 & 5 \\
& & Rp. 200.000.000.001- Rp. 400.000 .000 .000 & 10 \\
& & Rp. 400.000.000.001 - Rp. 600.000 .000 .000 & 15 \\
& & Rp. 600.000.000.001 - Rp. 800.000 .000 .000 & 20 \\
& & $>$ Rp. 800.000 .000 .000 & 25 \\
\hline
\end{tabular}

Badan Perijinan Terpadu dan/atau Kantor Perijinan Terpadu mempunyai tugas melaksanakan koordinasi dan menyelenggarakan pelayanan administrasi di bidang perijinan secara terpadu dengan prinsip koordinasi, integrasi, sinkronisasi,
Pengawasan penyelenggaraan pelayanan perijinan, dilakukan melalui: Pertama, Pengawasan melekat yaitu pengawasan yang dilakukan oleh atasan langsung sesuai dengan ketentuan peraturan perundang-undangan; Kedua, Pengawasan fung- 
Untuk Kota :

\begin{tabular}{clcc}
\hline No. & \multicolumn{1}{c}{ Variabel } & Kelas Interval & Nilai \\
\hline 1 & \multicolumn{1}{c}{2} & 3 & 4 \\
\hline 1. & JUMLAH PENDUDUK & 100.000 & 8 \\
& (jiwa) & $100.001-200.000$ & 16 \\
& Untuk Kota di & $200.001-300.000$ & 24 \\
& Pulau Jawa dan Madura & $300.001-400.000$ & 32 \\
& & $>400.000$ & 40 \\
2. & LUAS WILAYAH (km2) & 50 & 7 \\
& Untuk Kota di & $51-100$ & 14 \\
& Pulau Jawa dan Madura & $101-150$ & 21 \\
& & $151-200$ & 28 \\
& & $>200$ & 35 \\
3. JUMLAH APBD & Rp. 200.000.000.000 & 5 \\
& & Rp. 200.000.000.001 - Rp. 400.000.000.000 & 10 \\
& & Rp. 400.000.000.001 - Rp. 600.000.000.000 & 15 \\
& Rp. 600.000.000.001 - Rp. 800.000 .000 .000 & 20 \\
& & $>$ Rp. 800.000.000.000 & 25 \\
\hline
\end{tabular}

sional yaitu pengawasan yang dilakukan oleh aparat pengawasan fungsional sesuai dengan ketentuan peraturan perundang-undangan; Ketiga, Pengawasan masyarakat yaitu pengawasan yang dilakukan oleh masyarakat, berupa laporan atau pengaduan.

\section{PENUTUP}

Sistem pelayanan perijinan terpadu merupakan sistem yang seiring dengan paradigma baru dalam pelayanan publik sebagaimana yang dikehendaki oleh Reinventing Government. Sistem pelayanan perijinan terpadu merupakan hasil dari reformasi birokrasi. Reformasi birokrasi dengan menggunakan prinsip good governance akan didukung dengan kebijakan penyelenggaraan pelayanan perijinan terpadu. Kebijakan pemerintah dalam melaksanakan pelayanan perijinan terpadu, khususnya untuk pelayanan perijinan terpadu di daerah, nampaknya sudah dituangkan dalam peraturan perundang-undangan sebagai bagian dari deregulasi di bidang pelayanan perijinan di daerah, sehingga sudah ada landasan hukumnya dan tinggal menunggu implementasinya di masing-masing daerah.

\section{DAFTAR PUSTAKA}

Fanani, Ahmad Zaenal, 2010, Optimalisasi Pelayanan Publik: Perspektif David Osborne dan Ted Gaebler, didownload dari http:// www.badilag.net/data/ARTIKEL

JPIP (The Jawa Pos Institute of Pro-Otonomi), 2007, Paparan Hasil Monitoring Otonomi Daerah di Jatim, Memutus Rantai Panjang Layanan Publik.

Osborne, David dan Ted Gaebler, 1996, Mewirausahakan Birokrasi, terjemahan Abdul Rasyid, Jakarta: Pustaka Binaman Pressindo.

Undang-Undang Nomor 25 Tahun 2009 tentang Pelayanan Publik.

Peraturan Pemerintah Nomor 41 Tahun 2007 tentang Organisasi Perangkat Daerah.

Keputusan Menpan Nomor: 63/KEP/ M.PAN/7/ 2003 tentang Pedoman Umum Penyelenggaraan Pelayanan Publik.

Peraturan Menteri Dalam Negeri (Permendagri) Nomor 24 Tahun 2006 tentang Pedoman Penyelenggaraan Pelayanan Terpadu Satu Pintu (PPTSP).

Permendagri Nomor 20 Tahun 2008 tentang Pedoman Organisasi dan Tatakerja Unit Pelayanan Perijinan Terpadu di Daerah.

Peraturan Menteri Negara Pendayagunaan Aparatur Negara dan Reformasi Birokrasi Nomor 7 Tahun 2010 tentang Pedoman Penilaian Kinerja Unit Pelayanan Publik. 